\title{
REVIEW
}

\section{Renal recovery after acute kidney injury}

\author{
L. G. Forni ${ }^{1,2}$, M. Darmon ${ }^{3}$, M. Ostermann ${ }^{4}$, H. M. Oudemans-van Straaten ${ }^{5}$, V. Pettilä6 , J. R. Prowle ${ }^{7}$, M. Schetz ${ }^{8}$ \\ and M. Joannidis ${ }^{9^{*}}$
}

(c) 2017 The Author(s). This article is an open access publication

\begin{abstract}
Acute kidney injury (AKI) is a frequent complication of critical illness and carries a significant risk of short- and longterm mortality, chronic kidney disease (CKD) and cardiovascular events. The degree of renal recovery from AKI may substantially affect these long-term endpoints. Therefore maximising recovery of renal function should be the goal of any AKI prevention and treatment strategy. Defining renal recovery is far from straightforward due in part to the limitations of the tests available to assess renal function. Here, we discuss common pitfalls in the evaluation of renal recovery and provide suggestions for improved assessment in the future. We review the epidemiology of renal recovery and of the association between AKI and the development of CKD. Finally, we stress the importance of post-discharge follow-up of AKI patients and make suggestions for its incorporation into clinical practice. Summary key points are that risk factors for non-recovery of AKI are age, CKD, comorbidity, higher severity of AKI and acute disease scores. Second, AKI and CKD are mutually related and seem to have a common denominator. Third, despite its limitations full recovery of AKI may best be defined as the absence of AKI criteria, and partial recovery as a fall in AKI stage. Fourth, after an episode of AKI, serial follow-up measurements of serum creatinine and proteinuria are warranted to diagnose renal impairment and prevent further progression. Measures to promote recovery are similar to those preventing renal harm. Specific interventions promoting repair are still experimental.
\end{abstract}

Keywords: Acute kidney injury, Acute kidney disease, Chronic kidney disease, Renal replacement therapy, Follow-up, Biomarkers

\section{Introduction: why focus on recovery?}

While acute renal impairment is sometimes thought of as a relatively trivial insult defined purely by changes in serum creatinine, the introduction and subsequent acceptance of the concept of acute kidney injury (AKI) has gradually alerted critical care and nephrology clinicians to potential late complications in AKI survivors. It is well recognised that progressive or persistent impairment in renal function may occur following an episode of AKI, with the potential to progress to end-stage kidney disease (ESKD) with dialysis dependence. However, the outcome from an episode of AKI cannot simply be

\footnotetext{
*Correspondence: michael.joannidis@i-med.ac.at

${ }^{9}$ Division of Intensive Care and Emergency Medicine, Department of Internal Medicine, Medical University Innsbruck, Anichstrasse 35, 6020 Innsbruck, Austria

Full author information is available at the end of the article
}

regarded as the binary administration for chronic renal replacement therapy (RRT) or recovery. Several authors have highlighted the substantial risk of development and progression of chronic kidney disease (CKD), short of ESKD [1-11] which is in turn strongly associated with increased short- and long-term mortality $[10,12]$. This association does not necessarily implicate causation but could also indicate a common underlying disease process (Fig. 1). The question thus arises 'What do we mean by renal recovery after AKI?' Furthermore, in the absence of an effective therapy to alter the acute course of established AKI, our current focus should be turned towards both AKI prevention and promotion of kidney repair in the recovery phase.

\section{Pathophysiology of recovery}

The mechanisms underlying the renal repair process after AKI have predominantly been studied in animal models

\section{望




\section{Cardiovascular disease, AKI and ESRD}

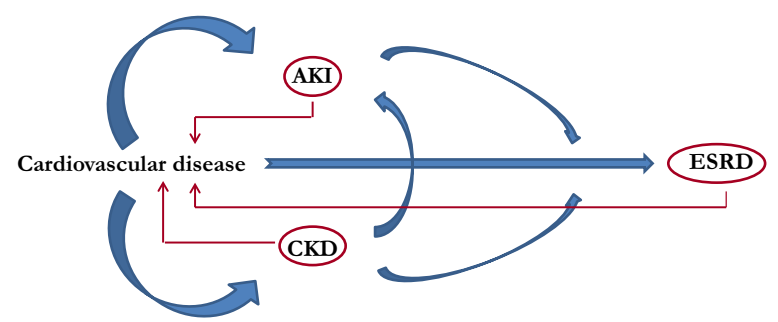

Fig. 1 Complex interrelationship between cardiovascular disease, acute kidney injury (AKI) and chronic kidney disease (CKD) as risk factors for end-stage renal disease (ESRD). High age, severe acute disease and possibly the modality of renal replacement therapy in patients with positive fluid balance are additional risk factors for progression to ESKD

of ischaemic AKI, characterized by loss of the brush border, principally in the proximal tubular epithelium, with inflammatory cell infiltration and epithelial cell sloughing, followed by repopulation of the damaged tubules by regenerating cells. After much debate as to whether the cells involved in this regenerative process are endogenous tubular epithelial cells, adult renal stem cells or bone marrow-derived stem cells, there is now increasing evidence that the repopulation mainly relies on surviving endogenous tubular cells with bone marrow-derived stem cells having at most a paracrine role through growth factor secretion [2].

Under certain circumstances, renal repair is maladaptive with inflammation, fibrosis and vascular rarefaction leading to persistent cell and tissue malfunction and eventually CKD. The frequency, severity, type and duration of injury as well the premorbid renal reserve (age, pre-existing CKD) seem to be risk factors for maladaptive repair. Both injured tubular epithelial cells and macrophages play an important role in this maladaptive repair process. Perturbations of the cell cycle with arrest in the $G_{2}$ phase and tubular cells failing to differentiate lead to production of proinflammatory and profibrotic signals and proliferation of the resident fibroblast population [2]. Whole organ gene expression profiling has been employed to identify molecular markers and regulatory pathways controlling the repair process [13] (Fig. 2). Understanding the mechanisms underlying maladaptive repair could potentially provide new targets for therapeutic intervention. In particular, strategies directed at inhibiting fibrosis or enhancing the endogenous repair processes may be promising.

\section{Clinical definition of renal recovery \\ Pitfalls in evaluation of recovery \\ Assessment of baseline function}

An adequate definition of renal recovery requires a reliable assessment of baseline kidney function to distinguish

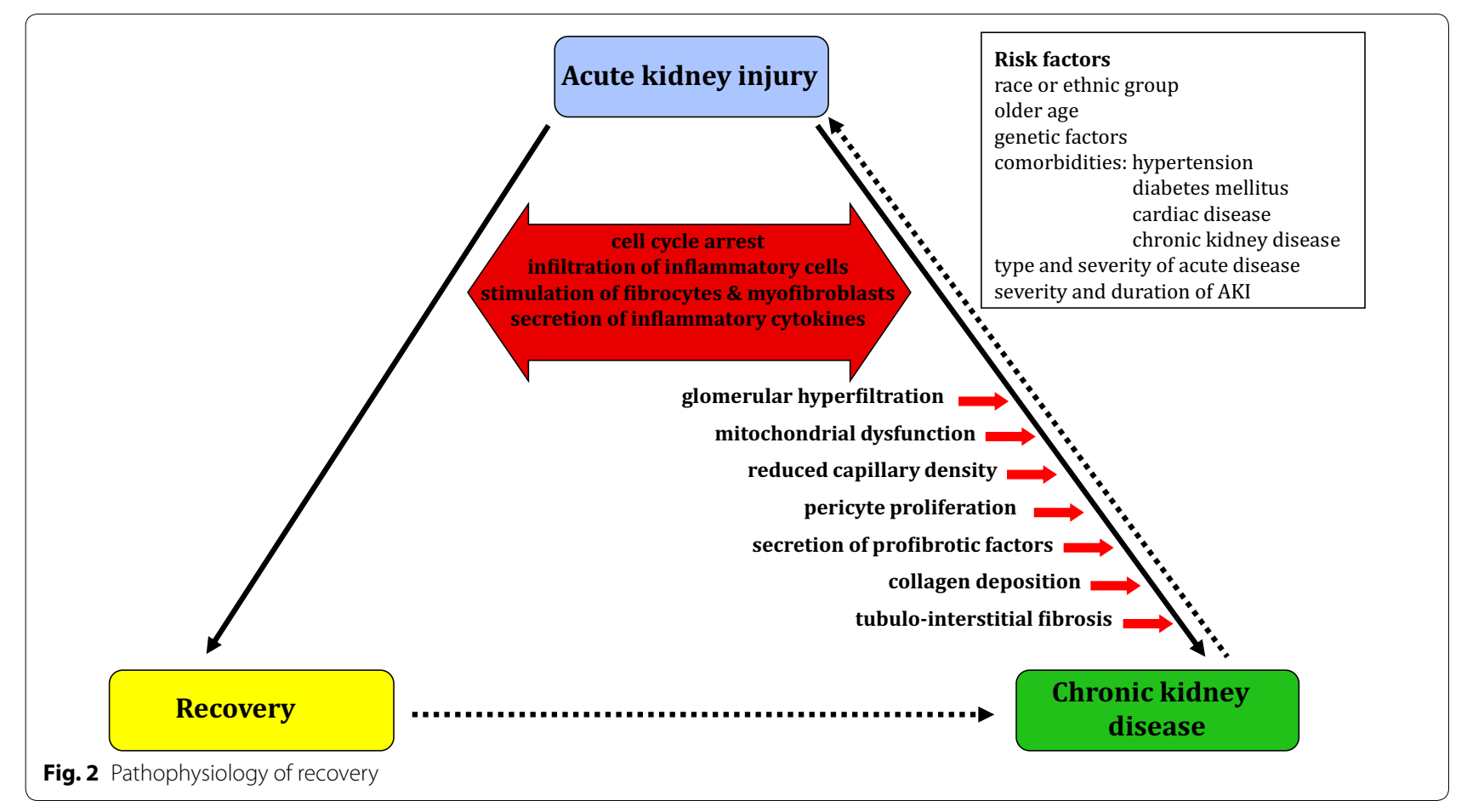


non-recovery from pre-existing CKD. Efforts to obtain baseline kidney function, e.g. from the primary care or referring specialists, are therefore of utmost importance. The mean outpatient serum creatinine $(\mathrm{SCr}$ ) (and the derived estimated glomerular filtration rate, eGFR) or, failing this, the most recent $\mathrm{SCr}$ measured between 7 and 365 days prior to the start of the acute illness is generally considered the best reflection of baseline kidney function [14]. Extremes in muscle mass or dietary protein intake may affect $\mathrm{SCr}$ independent of kidney function. Although use of cystatin $C$ and cystatin-based eGFR equations may reduce this problem [15], a baseline cystatin $C$ level is rarely available. Another potential shortcoming of $\mathrm{SCr}$, and the derived eGFR, is insensitivity to detect mild underlying CKD and the inability to detect the pre-existing presence or absence of renal functional reserve [16].

In the absence of a known baseline SCr the Kidney Diseases Improving Global outcomes (KDIGO) AKI workgroup suggests estimation of baseline through use of the Modification of Diet in Renal Disease (MDRD) equation [17]. This estimation assumes that patients have a baseline eGFR of $75 \mathrm{~mL} / \mathrm{min} / 1.73 \mathrm{~m}^{2}$, does not allow one to detect the presence of pre-existing CKD or wellpreserved renal function and will undoubtedly confound the evaluation of recovery [18]. In addition, the absence of a baseline $\mathrm{SCr}$ is usually non-random as demonstrated in a recent analysis which found less complete recovery in patients with unknown or missing baseline $\mathrm{SCr}$ compared with those with a known baseline [19]. An alternative is to use admission creatinine as a baseline. However, this ignores pre-admission AKI and has many other potential confounders including the absence of steady state, the effect of dilution after fluid resuscitation and reduced creatinine production in critical illness [20].

\section{Defining the population}

While most studies on renal recovery exclude prior ESKD (as defined by need for chronic dialysis), the handling of pre-existing CKD is variable. Furthermore, recovery has been reported in different populations (hospitalized versus ICU patients, general ICU versus specific surgical or medical populations, inclusion or exclusion of less severe forms of AKI). Whether recovery should be evaluated in all AKI patients or in survivors only depends on the setting. In a clinical trial evaluating an intervention to improve recovery, mortality should be treated as a competing endpoint. However, recovery in survivors may also be relevant to assess at the bedside [19].

\section{Timing of recovery assessment}

In the current literature, the timing for the evaluation of renal recovery varies considerably. Some studies determine "recovery" after 3-7 days to make the distinction between transient and persistent AKI. Recent evidence suggests that the time pattern of changes in kidney function and relapses after initial "reversal" may also be associated with mortality [12, 21]. Most studies report recovery at hospital discharge. However, its evaluation at a fixed time point, e.g. at 3 months, allowing one to mark the transition from AKI to CKD, would be more appropriate. Delaying the assessment might also reduce the problem of the impact of sarcopenia on SCr levels. The recent Acute Disease Quality Initiative (ADQI) conference suggests differentiating AKI (first 7 days) from acute kidney disease (AKD) (AKI persisting for 7-90 days) and CKD (after 90 days), which may provide a framework for defining recovery in terms of time after the sentinel event (Fig. 3). While AKD was initially proposed to encompass any acute condition that impacts on longer-term kidney function [22], this more recent ADQI proposal further refines the criteria with the addition of a staging system [23].

\section{Defining recovery}

In the past, renal recovery was often defined as independence from RRT following dialysis-requiring AKI. More recently, non-recovery from less severe AKI has received more attention due to its association with adverse longterm outcomes [1, 21]. Despite many limitations the most obvious definition of full recovery from AKI is the absence of AKI criteria. Partial recovery can then be defined as a fall in AKI stage. Recovery may occur early after the insult leading to AKI or later during the phase of AKD (Fig. 3). However, it is important to appreciate that the use of the creatinine criteria may result in important underestimation of recovery in patients with unknown premorbid creatinine [18] or overestimation of recovery by ignoring the loss of muscle mass that occurs during critical illness [19, 24]. Tubular secretion of creatinine, the contribution of which increases with decreasing GFR, also results in overestimation of GFR by creatinine clearance. An alternative definition of non-recovery might be the presence of eGFR criteria for new or worsening CKD [25], which, however, still relies on $\mathrm{SCr}$ with its associated shortcomings.

\section{Future directions}

An ideal definition of recovery would compare the gold standard of GFR measurement before and after the episode of AKI. Even better would be the inclusion of an assessment of renal functional reserve before and after the episode of AKI. However, outside predictable events such as elective major surgery, accrual of such data is highly unlikely. Despite this, there are potential avenues for improved assessment of renal recovery which are discussed below. 


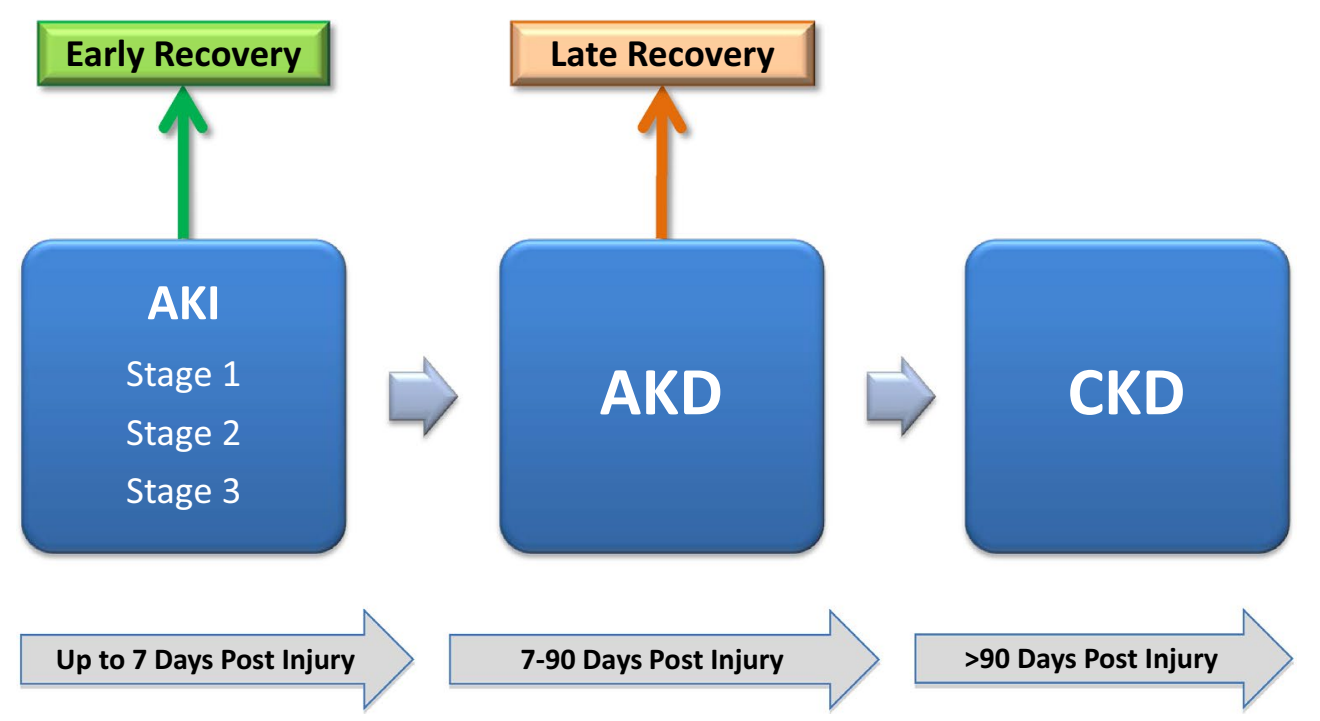

Fig. $3 \mathrm{AKI}, \mathrm{AKD}, \mathrm{CKD}$ and time course of recovery. Recovery may occur early during acute kidney injury (AKI) up to 7 days after the insult, or later during acute kidney disease (AKD), between 7 days and 3 months after the insult to the kidney

\section{Measurement of creatinine clearance}

A potential avenue for exploration is the determination of the measured creatinine clearance at ICU discharge from a timed urinary collection coupled with a serum creatinine determination. Such an estimate of GFR is not without its detractors but is readily available and economical. Since premorbid creatinine clearance will usually not be available, defining recovery by this parameter assumes that the estimation of premorbid GFR with predictive equations is reliable and does not account for overestimation of glomerular filtration by creatinine clearance due to tubular creatinine excretion [19]. However, measuring creatinine clearance at ICU or hospital discharge may serve as a baseline for the follow-up.

\section{Measurement of renal functional reserve}

Renal functional reserve is defined as the increase in GFR after a stress test (e.g. an acute protein load [26]). Its measurement is difficult to perform in the ICU and few, if any, patients have such data available prior to an AKI event. However, assessing renal reserve could be useful to identify patients who are at increased risk of further progressive CKD or recurrent AKI (Table 1).

\section{Kinetic eGFR}

Kinetic eGFR is a mathematical method to estimate underlying renal function from the rate of change of creatinine during non-steady state conditions and has been proposed for the earlier detection of changes in GFR, both during development and recovery of AKI $[27,28]$. However, in the critically ill there are several potential confounders that affect measured $\mathrm{SCr}$
Table 1 Risk factors for short-term non-recovery of renal function

\begin{tabular}{ll}
\hline Patient-related risk factors & Age \\
& Race ethnicity \\
& Genetic factors \\
& Chronic kidney disease \\
& Comorbidity \\
Severity of acute disease & High illness severity \\
& Haemodynamic instability \\
Severity of AKI & Medical admission \\
\hline
\end{tabular}

$A K I$ acute kidney injury, KDIGO kidney disease improving global outcomes

concentrations and the eGFR, including assumptions regarding maximal rise in creatinine, reductions in creatinine production and changes in the volume of distribution. Although in comparison with novel AKI biomarkers, this technique has been shown to perform as well or better in predicting short-term recovery of kidney function (within $48 \mathrm{~h}$ ) [28], the assumption that muscle mass is constant makes it less useful in assessing kidney function including recovery over a longer timeperiod in ICU patients. Measurement and correction of kinetic eGFR for muscle mass loss may be a way of improving this method.

\section{Real-time GFR monitoring}

Real-time GFR monitoring techniques are still experimental $[29,30]$, but nearing clinical implementation. The development of such systems will clearly aid in identifying individuals who have not recovered full function [31]. 


\section{Biomarkers for (non)recovery}

The limitations of both $\mathrm{SCr}$ and urine output as early indicators of AKI are well documented and have led to the pursuit of robust early markers of kidney damage. These biomarkers can be broadly classified as inflammatory biomarkers [e.g. neutrophil gelatinase-associated lipocalin (NGAL), interleukin (IL)-6 and IL-18], cell injury biomarkers [e.g. kidney injury molecule-1 (KIM-1) and liver fatty acid binding protein (L-FABP)] and markers of cell cycle arrest [e.g. insulin growth factor binding protein 7 (IGFBP7) and tissue inhibitor of metalloproteinase 2 (TIMP-2)] (Table 2).

Few studies have evaluated these classical injury markers for their ability to predict recovery. Currently, NGAL has received most attention in this context. Plasma NGAL, measured on the first day of AKI stage 3 , has been shown to be a reasonable predictor of failure to recover in a cohort of patients with communityacquired pneumonia, many of whom were not in the ICU [32]. A small substudy of the VA/NIH Acute Renal
Failure Trial Network Study found that, in addition to age and a high Charlson comorbidity index, higher concentrations of a panel of urinary biomarkers at day 14 after commencement of RRT may improve the prediction of non-recovery/dialysis dependence at 60 days [33]. However, the investigators used a combined endpoint of death or renal non-recovery and only had 25 deaths and 13 non-recovery patients. Similarly, a panel of biomarkers applied to patients with AKI requiring RRT demonstrated that decreasing urinary NGAL during the first 14 days following AKI was associated with a reduced need for renal support at 60 days [34]. This study clearly highlights the value of repeated measures over single values. KIM-1 and L-FABP have also been proposed as a marker of renal recovery after AKI $[35,36]$. Similarly the product of the more recently described $G_{1}$ cell cycle arrest markers of renal stress TIMP-2 and IGFBP7 ([TIMP-2] $\times$ [IGFBP7]) predicted short-term renal recovery/non-recovery within $48 \mathrm{~h}$ in 57 patients with early AKI [37].

Table 2 Biomarkers of short-term acute kidney injury (AKI) recovery versus persistence to acute kidney disease (AKD)

\begin{tabular}{|c|c|c|c|}
\hline AKI biomarker & Characteristics & Clinical setting & Outcome \\
\hline Angiotensinogen & 453 amino acid protein; precursor of angiotensin I & $\begin{array}{l}\text { Acute CRS } \\
\text { Cardiac surgery } \\
\text { ICU }\end{array}$ & AKI progression \\
\hline Cystatin C & $\begin{array}{l}13 \mathrm{kDa} \text { cysteine protease inhibitor produced by all nucleated human cells; under- } \\
\text { goes glomerular filtration }\end{array}$ & ICU & RRT \\
\hline Hepatocyte growth factor & $\begin{array}{l}\text { Antifibrotic cytokine produced by mesenchymal cells and involved in tubular cell } \\
\text { regeneration after AKI }\end{array}$ & ICU & RRT \\
\hline $\begin{array}{l}\text { IGFBP7 } \\
\text { TIMP-2 }\end{array}$ & $\begin{array}{l}29 \mathrm{kDa} \text { and } 21 \mathrm{kDa} \text { proteins involved in cell cycle arrest; released into urine after } \\
\text { tubular cell stress }\end{array}$ & $\begin{array}{l}\text { ICU } \\
\text { Cardiac surgery }\end{array}$ & RRT \\
\hline IL-18 & $\begin{array}{l}18 \text { kDa pro-inflammatory cytokine; regulates innate and adaptive immunity; } \\
\text { released into urine after proximal tubular cell injury }\end{array}$ & $\begin{array}{l}\text { ICU } \\
\text { Acute CRS } \\
\text { Cardiac surgery } \\
\text { Renal transplantation }\end{array}$ & $\begin{array}{l}\text { AKI progression } \\
\text { RRT } \\
\text { DGF }\end{array}$ \\
\hline KIM-1 & $\begin{array}{l}39 \mathrm{kDa} \text { transmembrane glycoprotein involved in tubular regeneration; released } \\
\text { into urine following ischaemic or nephrotoxic tubular cell damage }\end{array}$ & $\begin{array}{l}\text { ICU } \\
\text { Hospitalised patients } \\
\text { Renal transplantation }\end{array}$ & $\begin{array}{l}\text { AKI progression } \\
\text { Need for RRT } \\
\text { DGF }\end{array}$ \\
\hline L-FABP & $\begin{array}{l}14 \mathrm{kDa} \text { intracellular lipid chaperone produced in proximal tubular cells; aids in } \\
\text { regulation of fatty acid uptake and intracellular transport; excretion into urine } \\
\text { after tubular injury }\end{array}$ & $\begin{array}{l}\text { ICU } \\
\text { Cardiac surgery }\end{array}$ & $\begin{array}{l}\text { AKI progression } \\
\text { RRT }\end{array}$ \\
\hline MicroRNA & $\begin{array}{l}\text { Endogenous single-stranded molecules of non-coding nucleotides; upregulated } \\
\text { following tubular cell injury and cell proliferation; detectable in plasma and } \\
\text { urine }\end{array}$ & $\begin{array}{l}\text { ICU } \\
\text { Cardiac surgery }\end{array}$ & $\begin{array}{l}\text { AKI progression } \\
\text { RRT }\end{array}$ \\
\hline NAG & $\begin{array}{l}\text { >130 kDa lysosomal enzyme; produced in proximal and distal tubular cells; } \\
\text { released into urine after tubular cell injury }\end{array}$ & Hospitalised patients & RRT \\
\hline NGAL & $\begin{array}{l}\text { At least three different types: } \\
\text { Monomeric } 25 \mathrm{kDa} \text { glycoprotein produced by neutrophils and epithelial cells, } \\
\text { including renal tubules } \\
\text { Homodimeric } 45 \mathrm{kDa} \text { protein produced by neutrophils } \\
\text { Heterodimeric } 135 \mathrm{kDa} \text { protein produced by renal tubular cells released into } \\
\text { urine following systemic production or tubular injury }\end{array}$ & $\begin{array}{l}\text { ICU } \\
\text { Cardiac surgery } \\
\text { Acute CRS } \\
\text { Renal transplantation }\end{array}$ & $\begin{array}{l}\text { AKI progression } \\
\text { RRT } \\
\text { DGF }\end{array}$ \\
\hline
\end{tabular}

Relevant references are mentioned in the text

$A K I$ acute kidney injury, CRS cardiorenal syndrome, DGF delayed graft function, ICU intensive care unit, IGFBP-7 insulin-like growth factor binding protein 7 , IL-18 interleukin 18, L-FABP liver-type fatty acid-binding protein, KIM-1 kidney injury molecule-1, NAG N-acetyl- $\beta$-D-glucosaminidase, NGAL neutrophil gelatinase-associated lipocalin, TIMP-2 tissue metalloproteinase 2, RRT renal replacement therapy, $k D a$ kilodalton 
Even less data is available on biomarkers that are specific for the repair process. In the setting of CKD, transforming growth factor beta (TGF $\beta$ ), monocyte chemoattractant protein-1 (MCP-1) and matrix metalloproteinase protein-2 (MMP-2) have been shown to correlate with fibrosis and CKD progression [38]. After renal transplantation, urinary YKL-40, a repair phase protein, in the donor is independently associated with recovery from AKI and delayed graft function [39]. Dipstick albuminuria greater than $30 \mathrm{mg} / \mathrm{dL}$ is independently associated with lower rates of AKI recovery at 30 days in patients with sepsis [40]. Another promising biomarker for recovery is osteopontin [41, 42].

In general, trials evaluating biomarkers for prediction of recovery after AKI have been small and focussed predominantly on the differentiation between transient AKI and AKD.

Identification and Validation of Biomarkers of Acute Kidney Injury Recovery (ClinicalTrials.gov Identifier: NCT01868724) was a multicentre study to validate biomarkers specifically for major adverse kidney event (MAKE) and major adverse cardiac events (MACE) following an episode of AKI in ICU. The results are still awaited. Hopefully, the increasing insights into the molecular mechanisms of renal recovery will lead to new biomarkers specific to the repair process.

\section{Potential markers of tubular function}

One area that has received little attention in the post AKI period is that of tubular function. In CKD, proteinuria is the best predictor of both disease progression and ESKD over and above hypertension [43] which may arise because of both increased glomerular permeability and reduced tubular uptake of filtered protein. A few studies have highlighted that patients with preoperative proteinuria are at increased risk of AKI particularly after cardiac surgery [44, 45] and after severe burns [46]. Moreover, (tubular) proteinuria has been found to be associated with worse outcomes in the critically ill including the rate of AKI and long-term kidney function [47-49]. Other markers of tubular function have not been studied in any detail. Since proteinuria is known to be a modifiable risk factor in CKD, such assessment should be mandated in the follow-up of patients with AKI.

\section{Epidemiology of renal outcome after AKI Short-term renal outcome}

Rates of non-recovery from dialysis-requiring AKI differ dramatically among populations and can vary between $0 \%$ and $40 \%[12,50]$. Differences in the indications and thresholds for starting RRT may account for some variability. Other studies have evaluated recovery from all AKI (including less severe forms) and reported complete recovery rates between $33 \%$ and $90 \%$ [12, 19, 32, 51-57]. However, the use of different definitions of AKI (with or without inclusion of the urine output criteria, with inclusion or exclusion of less severe forms), different definitions of recovery, the variable case-mix (surgical, medical or mixed population, inclusion or exclusion of patients with CKD, evaluation in survivors only) and differences in timing of assessment of recovery prevent a direct comparison of the results. Last, inclusion of patients dying during ICU stay strongly affects recovery rate, recovery being a time-dependent process and death during ICU stay acting as a potent confounder [19].

\section{Long-term renal outcome}

The association between AKI and subsequent progression to CKD has been highlighted by recent epidemiological studies $[1,3,5,6,10,21,34,58-62]$, although a causal relation cannot be proven. The association between AKI and CKD is complex and multidirectional so that CKD evolution may be either through non-recovery from AKI, de-novo development of CKD after recovery from AKI or progression of pre-existing CKD. In patients without prior CKD who have complete recovery of renal function, the risk of progressive CKD may be low [63]. However other authors have demonstrated a substantial incidence of de novo CKD and death in survivors of AKI, including those who do not require RRT [60].

As outlined, most studies demonstrate that the risk for ESKD after AKI is increased (Table 3) [10, 62]. Most studies on long-term kidney outcome are limited to patients receiving RRT and suggest that dialysis dependency at 90 days may approach up to $30 \%[10,11,50,64$, 65]. A large Danish registry study comprising 3062 ICU patients treated with RRT (among a total of 107,937 ICU patients) suggested a 5-year cumulative risk of ESKD of $11.7 \%$ (95\% CI 10.5-13.0) [6] - in keeping with a Swedish registry study comprising 998 RRT-treated AKI patients [66]. The Danish registry study [6] revealed an adjusted HR of 105 (95\% CI 78-142) for ESKD at 180 days for RRT-treated AKI patients compared to other critically ill patients (Table 3). The absolute risk difference was highest among those RRT-AKI patients with preexisting CKD, and the relative risk of ESKD was highest among younger RRT-AKI patients, those with previous CKD, and those with elective surgery. Death and chronic dialysis treatment are competing risks which should be included in the analysis [67]. The follow-up study by the RENAL investigators [65] showed that the risk of dying was much greater than the risk of ESKD.

\section{Risk factors/predictors for non-recovery}

Risk factors for non-recovery after AKI include age, comorbidity, severity of acute disease and potentially the 
Table 3 Long-term risk of end-stage kidney disease (ESKD) after acute kidney injury (AKI) and renal replacement therapy (RRT) treated AKI

\begin{tabular}{lll}
\hline AKI stage & Absolute risk (\%)/at time & Hazard ratio, HR (95\% CI) over time \\
\hline AKI (all stages) vs. non-AKI & $2 \%$ vs. 0.08\%/1 year [62] & HR 3.1 (1.9-5.0) per 100 patient-years [10] \\
& $3.9 \%$ vs. 0.3\%/5 year & \\
RRT-treated AKI & 90 days: $30 \%[10,11,50], 25 \%$ [64], 5.4\% [65] & Up to 180 days: HR 105 (78-148) vs. critically ill [6] \\
& 180 days: $8.5 \%[6]$ & From 80 days to 5 years: HR 6.2(4.7-8.1) vs. critically ill [6] \\
& 1 year: $20 \%[64]$ & \\
& 5 years: $11.7 \%$ (cumulative risk) [6] & \\
& 7 years: $3.4 \%$ (new ESKD) [66] & \\
&
\end{tabular}

$H R$ hazard ratio, $\mathrm{Cl}$ confidence interval

modality of RRT $[64,68]$. Among patient-related risk factors for non-recovery, high age $[4,12,33,61]$, the presence of CKD [8, 12, 34, 61, 69] and comorbidities such as hypertension, diabetes mellitus and cardiac disease [12, $33,50]$ are the most frequently reported hazards. The common denominator is diminished glomerular reserve associated with age or chronic disease, suggesting a common underlying disease causing AKI and CKD. Type and severity of the acute disease process may also determine non-recovery. A high acuity of illness as reflected by higher APACHE or SAPS scores [12, 70, 71], a higher degree of haemodynamic instability [12, 34, 72], medical admission [12] or more severe AKI [12, 59, 73, 74] are additional risk factors for non-recovery. Interestingly, the evidence associating sepsis diagnosis with renal recovery after AKI is conflicting $[12,58]$. In summary, putative mechanisms predisposing to renal non-recovery are exposure of a relatively decreased nephron mass to greater injury coupled with impaired or maladaptive repair mechanisms associated with age or chronic disease.

In general, patients needing RRT have a higher mortality and risk of non-recovery [64, 71, 75, 76]. Whereas some data suggest that RRT may be independently associated with impaired recovery following AKI [75], this issue remains controversial because of numerous unmeasured confounding variables. The impact of RRT modality on recovery remains controversial, too. While retrospective cohort studies suggest that initial use of CRRT is associated with less CKD than intermittent haemodialysis $[64,66]$, not all studies support this notion [77]. A meta-analysis showed that the benefit of CRRT was based on results in observational studies but not randomised controlled trials (RCTs) [68]. Interestingly, a recent retrospective observational French study used marginal structural modelling and found no differences in 30-day mortality and dialysis dependence (combined primary outcome) between continuous and intermittent RRT in the overall population. However, continuous treatment was associated with better 30-day survival without dialysis in patients with fluid overload, while it was associated with worse outcome in patients without haemodynamic instability at commencement of RRT [78]. Another recent multicentre retrospective cohort evaluating 638 patients alive at hospital discharge could not demonstrate any difference in renal recovery after adjustment for covariates between patients treated with intermittent haemodialysis or continuous RRT [77]. The authors suggest that when initial RRT modality is chosen primarily on haemodynamics, renal recovery in survivors is comparable between both modalities. Altogether, risk factors for non-recovery of AKI are higher age, CKD, comorbidity, higher severity of AKI and acute disease scores, while intermittent haemodialysis seems to be associated with non-recovery in patients with fluid overload at commencement of RRT.

\section{Potential measures to promote renal recovery}

General measures aimed at preventing AKI and protecting the kidney function should increase the chances for recovery [22, 23, 79]. This includes avoiding hyperglycaemia and nephrotoxins as well as using strict therapeutic drug monitoring if applicable. Episodes of renal hypoperfusion should be avoided by ensuring haemodynamic stability and adapting RRT modality to the haemodynamic situation and the presence of fluid overload [77, 78]. Specific interventions to promote recovery are still experimental. Promotion of cell proliferation and renal repair by clusterin $[80,81]$ and/or reducing post-injury fibrosis by AT1 receptor antagonism [82], pyridoxamine [83], alpha klotho [84], endothelial sphingosine-1-phosphate receptor 1 [85] or PTBA analogues [83] are some approaches that have shown promising results in animal studies.

\section{Follow-up of AKI patients}

Which patients require follow-up?

Follow-up for development of CKD should be considered in all patients who developed AKI, irrespective of the apparent degree of renal recovery. Importantly, while only a small proportion of AKI survivors may develop ESKD over time, many instead die, especially from cardiovascular causes [86]. CKD is indeed strongly associated with cardiovascular morbidity and mortality [87, 88]. In 
younger survivors, development of hypertension and cardiovascular disease may accelerate CKD progression, so that ESKD may develop after many years even if there is an apparently good initial recovery. Thus, in all groups of AKI survivors there is great potential for interventions to improve longer-term outcomes.

\section{How to organize follow-up?}

In practice the main hurdle is identifying patients for follow-up. This can be problematic as hospital discharge may be many weeks or months following the episode of AKI with the discharging team often not involved in the active management of the patient during their critical illness. Currently only a minority of patients who require RRT in the ICU and recover renal function receive nephrology follow-up [89, 90], illustrating the need to establish robust mechanisms to ensure targeted AKI follow-up. Such services have been developed and piloted [91, 92], but generally remain dependent on referral of patients following inpatient nephrology consultation, emphasising the need for appropriate involvement of renal services as inpatients to allow appropriately targeted follow-up. Care pathways for follow-up should vary according to need. Patients with significant overt renal impairment at hospital discharge (e.g. eGFR less than $30 \mathrm{~mL} / \mathrm{min} / \mathrm{m}^{2}$ ) require reassessment of renal function, probably within 2 weeks of discharge. In others, reassessment of renal function at 90 days after insult is more appropriate, to allow time for both recovery of muscle mass and any further recovery of renal function, permitting a clearer assessment of the new baseline renal function (Fig. 4). Timing and location of follow-up will be

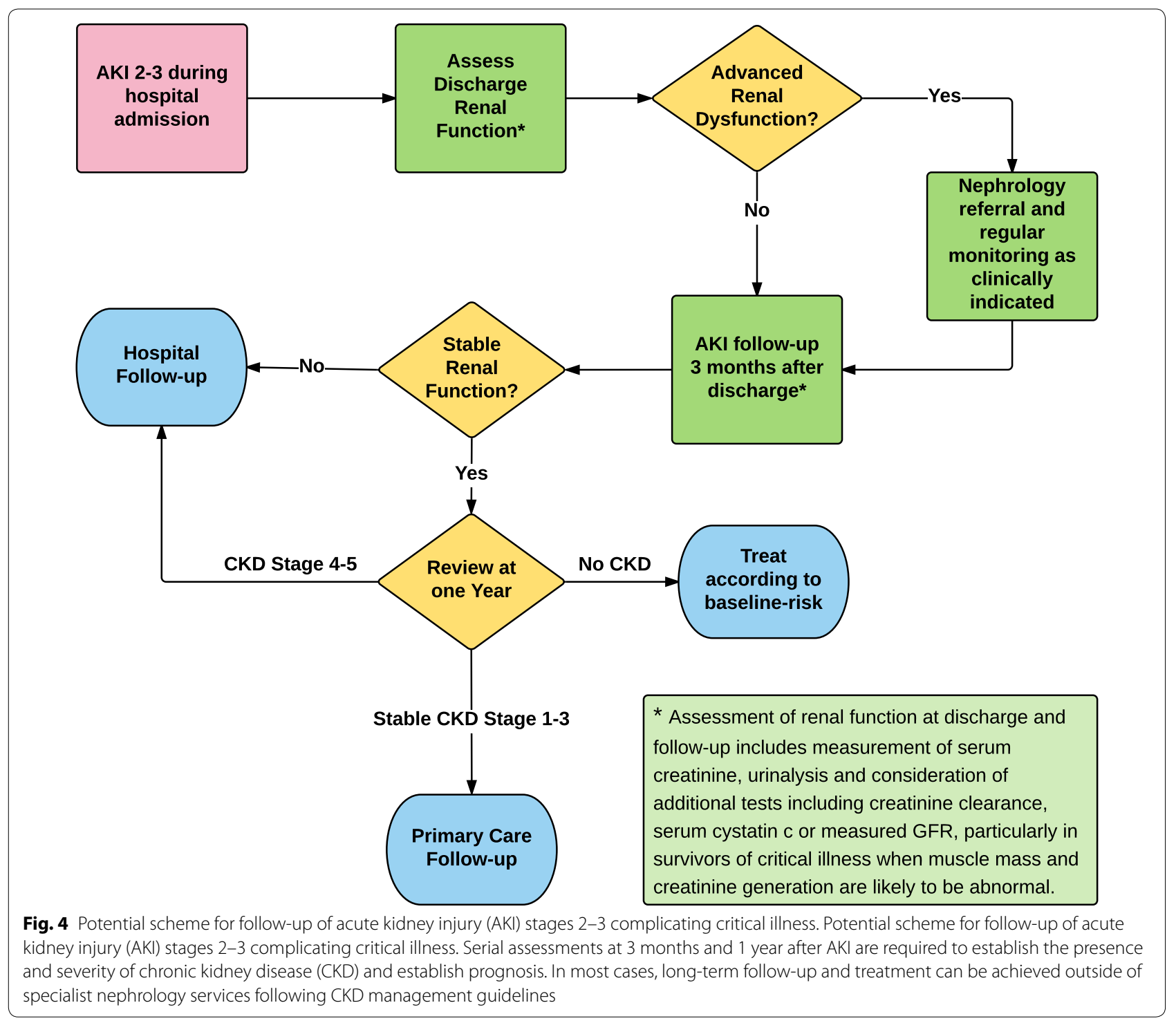


dependent on local resources; however, it is likely to be impracticable for all stage $1 \mathrm{AKI}$ to receive follow-up in secondary care. Effective long-term management of CKD can be achieved in primary care, but this is only possible if patients are identified at discharge and appropriate clinical guidelines are provided by specialists.

Survivors of severe AKI requiring RRT and those with more advanced CKD may specifically benefit from specialist nephrology review [93]. Even at 3 months, creatinine may not accurately reflect GFR in many survivors of critical illness. Measurement of serum cystatin C, urinary creatinine clearance or even, theoretically, formal measurement of GFR may be required in patients with significant loss of muscle mass. Besides measurement of GFR, CKD assessment requires an assessment of proteinuria (urinary protein-to-creatinine ratio). Proteinuria, a common outcome after AKI even in the absence of overt renal dysfunction [94], potentially indicates underlying hyperfiltration and loss of renal reserve; however, irrespective of the underlying mechanism, its clinical importance is clear as proteinuria is very strongly associated with cardiovascular risk and progression of CKD at all levels of GFR [87, 88].

Even in the absence of evidence of CKD at 90 days, survivors of significant AKI should have at least one further check for CKD criteria at 1 year to check for late progression. A recent single-centre study examined patients who had eGFR greater than $60 \mathrm{~mL} / \mathrm{min} / 1.73 \mathrm{~m}^{2} 12$ months or later after an episode of dialysis-treated AKI with a primary outcome of time to CKD as defined by eGFR persistently less than $60 \mathrm{~mL} / \mathrm{min} / 1.73 \mathrm{~m}^{2}$ [95]. Interestingly, in this cohort few patients with no CKD criteria function at 1 year developed CKD over a median 9 years of follow-up. In those who did risk factors for the development of longterm renal impairment consisted of older age, diabetes and known vascular disease. Thus, it may be reasonable to assume that AKI survivors without CKD at 1 year after illness are at low risk in the absence of other risk factors.

As the long-term ill effects of AKI are partially mediated through the development of CKD the management of these patients should follow general current well-developed clinical CKD guidelines [96]. Treatment of hypertension and modification of cardiovascular risk factors are central to management of patients with or at risk of CKD. In patients with diabetes or proteinuria, angiotensin converting enzyme (ACE) inhibitors or angiotensin-2 receptor blocking agents should be first-line drugs for hypertension, as these may reduce proteinuria and the rate of progression of CKD [97]. However, recurrent episodes of AKI are a concern, and any follow-up programme should address the prevention and early detection of new episodes of AKI, including the need for early assessment with new acute illness and advice regarding the avoidance of nephrotoxin exposure and adjustment of regular medication in the setting of illness [98].

\section{Conclusion}

The acceptance of a unifying definition of AKI has increased awareness of the syndrome and generated much knowledge on morbidity and outcome. Less attention has been given to recovery from AKI. Despite many limitations, non-recovery of AKI is best defined as the presence of AKI criteria, and partial recovery as a fall in AKI stage. Both are associated with the development of CKD and cardiovascular diseases, need of chronic dialysis and mortality. The incidence of nonrecovery differs between studies and populations. Risk factors include high age, CKD, comorbidity, higher severity of AKI and acute disease. After an episode of AKI serial follow-up measurements of serum creatinine and proteinuria are warranted to diagnose progressive renal impairment and implement measures to manage CKD if necessary.

\begin{abstract}
Author details
${ }^{1}$ Intensive Care Unit and Surrey Perioperative Anaesthesia and Critical Care Collaborative Research Group, Royal Surrey County Hospital NHS Foundation Trust, Egerton Road, Guildford, UK. ${ }^{2}$ Department of Clinical and Experimental Medicine, Faculty of Health and Medical Sciences, University of Surrey, Guildford, UK. ${ }^{3}$ Medical-Surgical ICU, Hopital Nord, CHU Saint-Etienne, Ave. Albert Raimon, 42270 Saint-Prient-en-Jarez, EA3065, Saint-Etienne, France.

${ }^{4}$ Department of Critical Care and Nephrology, Guy's and St Thomas' Hospital, London SE1 9RT, UK. ${ }^{5}$ Department of Intensive Care Medicine, VU University Medical Center Amsterdam, Amsterdam, The Netherlands. ${ }^{6}$ Division of Intensive Care Medicine, Department of Anesthesiology, Intensive Care and Pain Medicine, University of Helsinki and Helsinki University Hospital, Helsinki, Finland. ${ }^{7}$ William Harvey Research Institute, Queen Mary University of London and Adult Critical Care Unit, The Royal London Hospital, Barts Health NHS Trust, Whitechapel Road, London E1 1BB, UK. ${ }^{8}$ Division of Cellular and Molecular Medicine, Clinical Department and Laboratory of Intensive Care Medicine, KU Leuven University, Herestraat 49, 3000 Louvain, Belgium. ${ }^{9}$ Division of Intensive Care and Emergency Medicine, Department of Internal Medicine, Medical University Innsbruck, Anichstrasse 35, 6020 Innsbruck, Austria.
\end{abstract}

\section{Acknowledgements}

Open access funding provided by University of Innsbruck and Medical University of Innsbruck.

\section{Compliance with ethical standards}

Conflicts of interest

All authors declare that they have no conflict of interest.

\section{Open Access}

This article is distributed under the terms of the Creative Commons Attribution-NonCommercial 4.0 International License (http://creativecommons.org/ licenses/by-nc/4.0/), which permits any noncommercial use, distribution, and reproduction in any medium, provided you give appropriate credit to the original author(s) and the source, provide a link to the Creative Commons license, and indicate if changes were made.

Received: 22 February 2017 Accepted: 17 April 2017

Published online: 2 May 2017 


\section{References}

1. Xu JR, Zhu JM, Jiang J, Ding XQ, Fang Y, Shen B, Liu ZH, Zou JZ, Liu L, Wang CS, Ronco C, Liu H, Teng J (2015) Risk factors for long-term mortality and progressive chronic kidney disease associated with acute kidney injury after cardiac surgery. Medicine 94:e2025

2. Venkatachalam MA, Weinberg JM, Kriz W, Bidani AK (2015) Failed tubule recovery, AKI-CKD transition, and kidney disease progression. J Am Soc Nephrol 26:1765-1776

3. Varrier M, Forni LG, Ostermann M (2015) Long-term sequelae from acute kidney injury: potential mechanisms for the observed poor renal outcomes. Crit Care 19:102

4. Schmitt R, Coca S, Kanbay M, Tinetti ME, Cantley LG, Parikh CR (2008) Recovery of kidney function after acute kidney injury in the elderly: a systematic review and meta-analysis. Am J Kidney Dis 52:262-271

5. Pannu N, James M, Hemmelgarn B, Klarenbach S, Alberta Kidney Disease N (2013) Association between AKl, recovery of renal function, and longterm outcomes after hospital discharge. Clin J Am Soc Nephrol 8:194-202

6. Gammelager $\mathrm{H}$, Christiansen $\mathrm{CF}$, Johansen $\mathrm{MB}$, Tonnesen $\mathrm{E}$, Jespersen B, Sorensen HT (2013) Five-year risk of end-stage renal disease among intensive care patients surviving dialysis-requiring acute kidney injury: a nationwide cohort study. Crit Care 17:145

7. Basile DP, Bonventre JV, Mehta R, Nangaku M, Unwin R, Rosner MH, Kellum JA, Ronco C (2016) Progression after AKl: understanding maladaptive repair processes to predict and identify therapeutic treatments. J Am Soc Nephrol 27:687-697

8. Ali T, Khan I, Simpson W, Prescott G, Townend J, Smith W, Macleod A (2007) Incidence and outcomes in acute kidney injury: a comprehensive population-based study. J Am Soc Nephrol 18:1292-1298

9. Finkenstaedt JT, Merrill JP (1956) Renal function after recovery from acute renal failure. N Engl J Med 254:1023-1026

10. Coca SG, Singanamala S, Parikh CR (2012) Chronic kidney disease after acute kidney injury: a systematic review and meta-analysis. Kidney Int 81:442-448

11. Macedo E, Bouchard J, Mehta RL (2008) Renal recovery following acute kidney injury. Curr Opin Crit Care 14:660-665

12. Kellum JA, Sileanu FE, Bihorac A, Hoste EA, Chawla LS (2017) Recovery after acute kidney injury. Am J Respir Crit Care Med 195:784-791

13. Kumar S, Liu J, McMahon AP (2014) Defining the acute kidney injury and repair transcriptome. Semin Nephrol 34:404-417

14. Siew ED, Ikizler TA, Matheny ME, Shi Y, Schildcrout JS, Danciu I, Dwyer JP, Srichai M, Hung AM, Smith JP, Peterson JF (2012) Estimating baseline kidney function in hospitalized patients with impaired kidney function. Clin J Am Soc Nephrol 7:712-719

15. Carlier M, Dumoulin A, Janssen A, Picavet S, Vanthuyne S, Van Eynde R, Vanholder R, Delanghe J, De Schoenmakere G, De Waele JJ, Hoste EA (2015) Comparison of different equations to assess glomerular filtration in critically ill patients. Intensive Care Med 41:427-435

16. Ronco C, Rosner MH (2012) Acute kidney injury and residual renal function. Crit Care 16:144

17. Siew ED, Matheny ME (2015) Choice of reference serum creatinine in defining acute kidney injury. Nephron 131:107-112

18. Bernardi MH, Schmidlin D, Ristl R, Heitzinger C, Schiferer A, Neugebauer T, Wrba T, Hiesmayr M, Druml W, Lassnigg A (2016) Serum creatinine backestimation in cardiac surgery patients: misclassification of AKI using existing formulae and a data-driven model. Clin J Am Soc Nephrol 11:395-404

19. Schetz M, Gunst J, De Vlieger G, Van den Berghe G (2015) Recovery from AKI in the critically ill: potential confounders in the evaluation. Intensive Care Med 41:1648-1657

20. Prowle JR (2013) Acute kidney injury: creatinine and AKI—through a glass, darkly. Nat Rev Nephrol 9:193-195

21. Heung M, Steffick DE, Zivin K, Gillespie BW, Banerjee T, Hsu CY, Powe NR, Pavkov ME, Williams DE, Saran R, Shahinian VB, Centers for Disease Control and Prevention CKD Surveillance Team (2016) Acute kidney injury recovery pattern and subsequent risk of CKD: an analysis of veterans health administration data. Am J Kidney Dis 67:742-752

22. Kidney Disease: Improving Global Outcomes (KDIGO) Acute Kidney Injury Work Group (2012) KDIGO clinical practice guideline for acute kidney injury. Kidney Inter 2:1-138

23. Chawla LS, Bellomo R, Bihorac A, Goldstein SL, Siew ED, Bagshaw SM, Bittleman D, Cruz D, Endre Z, Fitzgerald RL, Forni L, Kane-Gill SL, Hoste E, Koyner J, Liu KD, Macedo E, Mehta R, Murray P, Nadim M, Ostermann
M, Palevsky PM, Pannu N, Rosner M, Wald R, Zarbock A, Ronco C, Kellum JA, Acute Disease Quality Initiative Workgroup 16 (2017) Acute kidney disease and renal recovery: consensus report of the Acute Disease Quality Initiative (ADQI) 16 Workgroup. Nat Revi Nephrol 13:241-257

24. Prowle JR, Kolic I, Purdell-Lewis J, Taylor R, Pearse RM, Kirwan CJ (2014) Serum creatinine changes associated with critical illness and detection of persistent renal dysfunction after AKI. Clin J Am Soc Nephrol 9:1015-1023

25. Stevens PE, Levin A (2013) Evaluation and management of chronic kidney disease: synopsis of the kidney disease: improving global outcomes 2012 clinical practice guideline. Ann Intern Med 158:825-830

26. Doig GS, Simpson F, Bellomo R, Heighes PT, Sweetman EA, Chesher D, Pollock C, Davies A, Botha J, Harrigan P, Reade MC (2015) Intravenous amino acid therapy for kidney function in critically ill patients: a randomized controlled trial. Intensive Care Med 41:1197-1208

27. Chen S (2013) Retooling the creatinine clearance equation to estimate kinetic GFR when the plasma creatinine is changing acutely. J Am Soc Nephrol 24:877-888

28. Dewitte A, Joannes-Boyau O, Sidobre C, Fleureau C, Bats ML, Derache P, Leuillet S, Ripoche J, Combe C, Ouattara A (2015) Kinetic eGFR and novel AKI biomarkers to predict renal recovery. Clin J Am Soc Nephrol 10:1900-1910

29. Wang E, Meier DJ, Sandoval RM, Von Hendy-Willson VE, Pressler BM, Bunch RM, Alloosh M, Sturek MS, Schwartz GJ, Molitoris BA (2012) A portable fiberoptic ratiometric fluorescence analyzer provides rapid point-ofcare determination of glomerular filtration rate in large animals. Kidney Int 81:112-117

30. Rajagopalan R, Neumann WL, Poreddy AR, Fitch RM, Freskos JN, Asmelash B, Gaston KR, Galen KP, Shieh JJ, Dorshow RB (2011) Hydrophilic pyrazine dyes as exogenous fluorescent tracer agents for real-time point-of-care measurement of glomerular filtration rate. J Med Chem 54:5048-5058

31. Molitoris BA, Reilly ES (2016) Quantifying glomerular filtration rates in acute kidney injury: a requirement for translational success. Semin Nephrol 36:31-41

32. Srisawat N, Murugan R, Lee M, Kong L, Carter M, Angus DC, Kellum JA, Genetic, Inflammatory Markers of Sepsis Study I (2011) Plasma neutrophil gelatinase-associated lipocalin predicts recovery from acute kidney injury following community-acquired pneumonia. Kidney Int 80:545-552

33. Srisawat $N$, Wen $X$, Lee $M$, Kong L, Elder M, Carter M, Unruh M, Finkel K, Vijayan A, Ramkumar M, Paganini E, Singbartl K, Palevsky PM, Kellum JA (2011) Urinary biomarkers and renal recovery in critically ill patients with renal support. Clin J Am Soc Nephrol 6:1815-1823

34. Lin YF, Ko WJ, Chu TS, Chen YS, Wu VC, Chen YM, Wu MS, Chen YW, Tsai CW, Shiao CC, Li WY, Hu FC, Tsai PR, Tsai TJ, Wu KD, NSARF Study Group (2009) The 90-day mortality and the subsequent renal recovery in critically ill surgical patients requiring acute renal replacement therapy. Am J Surg 198:325-332

35. Ko GJ, Grigoryev N, Linfert D, Jang HR, Watkins T, Cheadle C, Racusen L, Rabb H (2010) Transcriptional analysis of kidneys during repair from AKI reveals possible roles for NGAL and KIM-1 as biomarkers of AKI-to-CKD transition. Am J Physiol Renal Physiol 298:F1472-F1483

36. Zeng X-F, Li J-M, Tan Y, Wang Z-F, He Y, Chang J, Zhang H, Zhao H, Bai X, Xie F, Sun J, Zhang $Y$ (2014) Performance of urinary NGAL and L-FABP in predicting acute kidney injury and subsequent renal recovery: a cohort study based on major surgeries. Clin Chem Lab Med 52:671

37. Dewitte $A$, Joannès-Boyau $O$, Sidobre $C$, Fleureau $C$, Bats M-L, Derache $P$, Leuillet S, Ripoche J, Combe C, Ouattara A (2015) Kinetic eGFR and novel AKI biomarkers to predict renal recovery. Clin J Am Soc Nephrol 10:1900

38. Mansour SG, Puthumana J, Coca SG, Gentry M, Parikh CR (2017) Biomarkers for the detection of renal fibrosis and prediction of renal outcomes: a systematic review. BMC Nephrol 18:72

39. Puthumana J, Hall IE, Reese PP, Schroppel B, Weng FL, Thiessen-Philbrook H, Doshi MD, Rao V, Lee CG, Elias JA, Cantley LG, Parikh CR (2017) YKL-40 associates with renal recovery in deceased donor kidney transplantation. J Am Soc Nephrol 28:661-670

40. Neyra JA, Manllo J, Li X, Jacobsen G, Yee J, Yessayan L, AKICI Study Group (2014) Association of de novo dipstick albuminuria with severe acute kidney injury in critically ill septic patients. Nephron Clin Pract 128:373-380

41. Levitsky J, Baker TB, Jie C, Ahya S, Levin M, Friedewald J, Al-Saden P, Salomon DR, Abecassis MM (2014) Plasma protein biomarkers enhance the clinical prediction of kidney injury recovery in patients undergoing liver transplantation. Hepatology 60:2017-2026 
42. Yang T, Sun S, Zhao Y, Liu Q, Han M, Lin L, Su B, Huang S, Yang L (2017) Biomarkers upon discontinuation of renal replacement therapy predict 60-day survival and renal recovery in critically ill patients with acute kidney injury. Hemodial Int. doi:10.1111/hdi.12532

43. Ruggenenti P, Perna A, Mosconi L, Matalone M, Pisoni R, Gaspari F, Remuzzi G (1997) Proteinuria predicts end-stage renal failure in nondiabetic chronic nephropathies. The "Gruppo Italiano di Studi Epidemiologici in Nefrologia" (GISEN). Kidney Int Suppl 63:S54-57

44. Huang TM, Wu VC, Young GH, Lin YF, Shiao CC, Wu PC, Li WY, Yu HY, Hu FC, Lin JW, Chen YS, Lin YH, Wang SS, Hsu RB, Chang FC, Chou NK, Chu TS, Yeh YC, Tsai PR, Huang JW, Lin SL, Chen YM, Ko WJ, Wu KD, National Taiwan University Hospital Study Group of Acute Renal Failure (2011) Preoperative proteinuria predicts adverse renal outcomes after coronary artery bypass grafting. J Am Soc Nephrol 22:156-163

45. Molnar AO, Parikh CR, Sint K, Coca SG, Koyner J, Patel UD, Butrymowicz I, Shlipak M, Garg AX (2012) Association of postoperative proteinuria with AKI after cardiac surgery among patients at high risk. Clin J Am Soc Nephrol 7:1749-1760

46. Hu JY, Meng XC, Han J, Xiang F, Fang YD, Wu J, Peng YZ, Wu YZ, Huang YS, Luo QZ (2012) Relation between proteinuria and acute kidney injury in patients with severe burns. Crit Care 16:R172

47. Han SS, Ahn SY, Ryu J, Baek SH, Chin HJ, Na KY, Chae DW, Kim S (2014) Proteinuria and hematuria are associated with acute kidney injury and mortality in critically ill patients: a retrospective observational study. BMC Nephrol 15:93

48. Horne KL, Packington R, Monaghan J, Reilly T, Mclntyre CW, Selby NM (2014) The effects of acute kidney injury on long-term renal function and proteinuria in a general hospitalised population. Nephron Clin Pract 128:192-200

49. Lim CT, Tan HK, Lau YK (2014) The significance of tubular and glomerular proteinuria in critically ill patients with severe acute kidney injury. Pak J Med Sci 30:1186-1190

50. Bagshaw SM (2006) Epidemiology of renal recovery after acute renal failure. Curr Opin Crit Care 12:544-550

51. Alves SC, Tomasi CD, Constantino L, Giombelli V, Candal R, Bristot Mde L, Topanotti MF, Burdmann EA, Dal-Pizzol F, Fraga CM, Ritter C (2013) Hypomagnesemia as a risk factor for the non-recovery of the renal function in critically ill patients with acute kidney injury. Nephrol Dial Transpl 28:910-916

52. Bihorac A, Yavas S, Subbiah S, Hobson CE, Schold JD, Gabrielli A, Layon AJ, Segal MS (2009) Long-term risk of mortality and acute kidney injury during hospitalization after major surgery. Ann Surg 249:851-858

53. Gammelager $\mathrm{H}$, Christiansen $\mathrm{CF}$, Johansen MB, Tonnesen $\mathrm{E}$, Jespersen B, Sorensen HT (2014) Three-year risk of cardiovascular disease among intensive care patients with acute kidney injury: a population-based cohort study. Crit Care 18:492

54. Garzotto F, Piccinni P, Cruz D, Gramaticopolo S, Dal Santo M, Aneloni G, Kim JC, Rocco M, Alessandri E, Giunta F, Michetti V, lannuzzi M, Belluomo Anello C, Brienza N, Carlini M, Pelaia P, Gabbanelli V, Ronco C (2011) RIFLEbased data collection/management system applied to a prospective cohort multicenter Italian study on the epidemiology of acute kidney injury in the intensive care unit. Blood Purif 31:159-171

55. Harris DG, Koo G, McCrone MP, Scalea TM, Chiu WC, Diaz JJ, Lissauer ME (2014) Recurrent kidney injury in critically ill surgical patients is common and associated with worse outcomes. JTrauma Acute Care Surg 76:1397-1401

56. Helgadottir S, Sigurdsson MI, Palsson R, Helgason D, Sigurdsson GH, Gudbjartsson T (2016) Renal recovery and long-term survival following acute kidney injury after coronary artery surgery: a nationwide study. Acta Anaesthesiol Scand 60:1230-1240

57. Kellum JA, Chawla LS, Keener C, Singbartl K, Palevsky PM, Pike FL, Yealy DM, Huang DT, Angus DC (2016) The effects of alternative resuscitation strategies on acute kidney injury in patients with septic shock. Am J Respir Crit Care Med 193:281-287

58. Bagshaw SM, Uchino S, Bellomo R, Morimatsu H, Morgera S, Schetz M, Tan I, Bouman C, Macedo E, Gibney N, Tolwani A, Oudemans-van Straaten HM, Ronco C, Kellum JA, Beginning and Ending Supportive Therapy for the Kidney (BEST Kidney) Investigators (2007) Septic acute kidney injury in critically ill patients: clinical characteristics and outcomes. Clin J Am Soc Nephrol 2:431-439

59. Chawla LS, Amdur RL, Amodeo S, Kimmel PL, Palant CE (2011) The severity of acute kidney injury predicts progression to chronic kidney disease. Kidney Int 79:1361-1369
60. Lai CF, Wu VC, Huang TM, Yeh YC, Wang KC, Han YY, Lin YF, Jhuang YJ, Chao CT, Shiao CC, Tsai PR, Hu FC, Chou NK, Ko WJ, Wu KD, National Taiwan University Hospital Study Group on Acute Renal Failure (2012) Kidney function decline after a non-dialysis-requiring acute kidney injury is associated with higher long-term mortality in critically ill survivors. Crit Care 16:R123

61. Macedo E, Zanetta DM, Abdulkader RC (2012) Long-term follow-up of patients after acute kidney injury: patterns of renal functional recovery. PLoS One 7:e36388

62. Rimes-Stigare C, Frumento P, Bottai M, Martensson J, Martling CR, Walther SM, Karlstrom G, Bell M (2015) Evolution of chronic renal impairment and long-term mortality after de novo acute kidney injury in the critically ill; a Swedish multi-centre cohort study. Crit Care 19:221

63. Schiffl H, Lang SM, Fischer R (2012) Long-term outcomes of survivors of ICU acute kidney injury requiring renal replacement therapy: a 10-year prospective cohort study. Clin Kidney J 5:297-302

64. Wald R, Shariff SZ, Adhikari NK, Bagshaw SM, Burns KE, Friedrich JO, Garg AX, Harel Z, Kitchlu A, Ray JG (2014) The association between renal replacement therapy modality and long-term outcomes among critically ill adults with acute kidney injury: a retrospective cohort study. Crit Care Med 42:868-877

65. Gallagher M, Cass A, Bellomo R, Finfer S, Gattas D, Lee J, Lo S, McGuinness S, Myburgh J, Parke R, Rajbhandari D, POST-RENAL Study Investigators and the ANZICS Clinical Trials Group (2014) Long-term survival and dialysis dependency following acute kidney injury in intensive care: extended follow-up of a randomized controlled trial. PLoS Med 11:e1001601

66. Bell M, SWING, Granath F, Schon S, Ekbom A, Martling CR (2007) Continuous renal replacement therapy is associated with less chronic renal failure than intermittent haemodialysis after acute renal failure. Intensive Care Med 33:773-780

67. Harel Z, Bell CM, Dixon SN, McArthur E, James MT, Garg AX, Harel S, Silver $S$, Wald R (2014) Predictors of progression to chronic dialysis in survivors of severe acute kidney injury: a competing risk study. BMC Nephrol 15:114

68. Schneider AG, Bellomo R, Bagshaw SM, Glassford NJ, Lo S, Jun M, Cass A, Gallagher M (2013) Choice of renal replacement therapy modality and dialysis dependence after acute kidney injury: a systematic review and meta-analysis. Intensive Care Med 39:987-997

69. Uehlinger DE, Jakob SM, Ferrari P, Eichelberger M, Huynh-Do U, Marti HP, Mohaupt MG, Vogt B, Rothen HU, Regli B, Takala J, Frey FJ (2005) Comparison of continuous and intermittent renal replacement therapy for acute renal failure. Nephrol Dial Transpl 20:1630-1637

70. Mehta RL, McDonald B, Gabbai FB, Pahl M, Pascual MT, Farkas A, Kaplan RM, Collaborative Group for Treatment of ARFitICU (2001) A randomized clinical trial of continuous versus intermittent dialysis for acute renal failure. Kidney Int 60:1154-1163

71. Bouchard J, Acharya A, Cerda J, Maccariello ER, Madarasu RC, Tolwani AJ, Liang X, Fu P, Liu ZH, Mehta RL (2015) A prospective international multicenter study of AKI in the intensive care unit. Clin J Am Soc Nephrol 10:1324-1331

72. Augustine JJ, Sandy D, Seifert TH, Paganini EP (2004) A randomized controlled trial comparing intermittent with continuous dialysis in patients with ARF. Am J Kidney Dis 44:1000-1007

73. Uchino S, Bellomo R, Morimatsu H, Morgera S, Schetz M, Tan I, Bouman C, Macedo E, Gibney N, Tolwani A, Straaten HO, Ronco C, Kellum JA (2009) Discontinuation of continuous renal replacement therapy: a post hoc analysis of a prospective multicenter observational study. Crit Care Med 37:2576-2582

74. Ishani A, Nelson D, Clothier B, Schult T, Nugent S, Greer N, Slinin Y, Ensrud KE (2011) The magnitude of acute serum creatinine increase after cardiac surgery and the risk of chronic kidney disease, progression of kidney disease, and death. Arch Intern Med 171:226-233

75. Clark EG, Bagshaw SM (2015) Unnecessary renal replacement therapy for acute kidney injury is harmful for renal recovery. Semin Dial 28:6-11

76. Elseviers MM, Lins RL, Van der Niepen P, Hoste E, Malbrain ML, Damas P, Devriendt J, SHARF investigators (2010) Renal replacement therapy is an independent risk factor for mortality in critically ill patients with acute kidney injury. Crit Care 14:R221

77. Liang KV, Sileanu FE, Clermont G, Murugan R, Pike F, Palevsky PM, Kellum JA (2016) Modality of RRT and recovery of kidney function after AKI in patients surviving to hospital discharge. Clin J Am Soc Nephrol 11:30-38 
78. Truche AS, Darmon M, Bailly S, Clec'h C, Dupuis C, Misset B, Azoulay E, Schwebel C, Bouadma L, Kallel H, Adrie C, Dumenil AS, Argaud L, Marcotte G, Jamali S, Zaoui P, Laurent V, Goldgran-Toledano D, Sonneville R, Souweine B, Timsit JF, OUTCOMEREA Study Group (2016) Continuous renal replacement therapy versus intermittent hemodialysis in intensive care patients: impact on mortality and renal recovery. Intensive Care Med 42:1408-1417

79. Joannidis M, DrumI W, Forni LG, Groeneveld AB, Honore P, Oudemans-van Straaten HM, Ronco C, Schetz MR, Woittiez AJ (2010) Prevention of acute kidney injury and protection of renal function in the intensive care unit. Expert opinion of the Working Group for Nephrology, ESICM. Intensive Care Med 36:392-411

80. Guo J, Guan Q, Liu X, Wang H, Gleave ME, Nguan CY, Du C (2016) Relationship of clusterin with renal inflammation and fibrosis after the recovery phase of ischemia-reperfusion injury. BMC Nephrol 17:133

81. Nguan CY, Guan Q, Gleave ME, Du C (2014) Promotion of cell proliferation by clusterin in the renal tissue repair phase after ischemia-reperfusion injury. Am J Physiol Renal Physiol 306:F724-733

82. Rodriguez-Romo R, Benitez K, Barrera-Chimal J, Perez-Villalva R, Gomez A, Aguilar-Leon D, Rangel-Santiago JF, Huerta S, Gamba G, Uribe N, Bobadilla NA (2016) AT1 receptor antagonism before ischemia prevents the transition of acute kidney injury to chronic kidney disease. Kidney Int 89:363-373

83. Skrypnyk NI, Voziyan P, Yang H, de Caestecker CR, Theberge MC, Drouin M, Hudson B, Harris RC, de Caestecker MP (2016) Pyridoxamine reduces postinjury fibrosis and improves functional recovery after acute kidney injury. Am J Physiol Renal Physiol 311:F268-277

84. Shi M, Flores B, Gillings N, Bian A, Cho HJ, Yan S, Liu Y, Levine B, Moe OW, Hu MC (2016) aKlotho mitigates progression of AKI to CKD through activation of autophagy. J Am Soc Nephrol 27:2331-2345

85. Perry HM, Huang L, Ye H, Liu C, Sung SJ, Lynch KR, Rosin DL, Bajwa A, Okusa MD (2016) Endothelial sphingosine 1-phosphate receptor-1 mediates protection and recovery from acute kidney injury. J Am Soc Nephrol 27:3383-3393

86. Wu VC, Wu CH, Huang TM, Wang CY, Lai CF, Shiao CC, Chang CH, Lin SL, Chen YY, Chen YM, Chu TS, Chiang WC, Wu KD, Tsai PR, Chen L, Ko WJ, NSARF Group (2014) Long-term risk of coronary events after AKI. J Am Soc Nephrol 25:595-605

87. Matsushita K, Coresh J, Sang Y, Chalmers J, Fox C, Guallar E, Jafar T, Jassal SK, Landman GW, Muntner P, Roderick P, Sairenchi T, Schottker B, Shankar A, Shlipak M, Tonelli M, Townend J, van Zuilen A, Yamagishi K, Yamashita K, Gansevoort R, Sarnak M, Warnock DG, Woodward M, Arnlov J, CKD Prognosis Consortium (2015) Estimated glomerular filtration rate and albuminuria for prediction of cardiovascular outcomes: a collaborative meta-analysis of individual participant data. Lancet Diabetes Endocrinol 3:514-525

88. Levey AS, de Jong PE, Coresh J, El Nahas M, Astor BC, Matsushita K, Gansevoort RT, Kasiske BL, Eckardt KU (2011) The definition, classification, and prognosis of chronic kidney disease: a KDIGO controversies conference report. Kidney Int 80:17-28

89. Siew ED, Peterson JF, Eden SK, Hung AM, SperoffT, Ikizler TA, Matheny ME (2012) Outpatient nephrology referral rates after acute kidney injury. J Am Soc Nephrol 23:305-312

90. Kirwan CJ, Blunden MJ, Dobbie H, James A, Nedungadi A, Prowle JR (2015) Critically ill patients requiring acute renal replacement therapy are at an increased risk of long-term renal dysfunction, but rarely receive specialist nephrology follow-up. Nephron 129:164-170

91. Silver SA, Goldstein SL, Harel Z, Harvey A, Rompies EJ, Adhikari NK, Acedillo R, Jain AK, Richardson R, Chan CT, Chertow GM, Bell CM, Wald R (2015) Ambulatory care after acute kidney injury: an opportunity to improve patient outcomes. Can J Kidney Health Dis 2:36

92. Silver SA, Harel Z, Harvey A, Adhikari NK, Slack A, Acedillo R, Jain AK, Richardson RM, Chan CT, Chertow GM, Bell CM, Wald R (2015) Improving care after acute kidney injury: a prospective time series study. Nephron 131:43-50

93. Harel Z, Wald R, Bargman JM, Mamdani M, Etchells E, Garg AX, Ray JG, Luo J, Li P, Quinn RR, Forster A, Perl J, Bell CM (2013) Nephrologist follow-up improves all-cause mortality of severe acute kidney injury survivors. Kidney Int 83:901-908

94. Bolanos JA, Yuan CM, Little DJ, Oliver DK, Howard SR, Abbott KC, Olson SW (2015) Outcomes after post-traumatic AKI requiring RRT in United States military service members. Clin J Am Soc Nephrol 10:1732-1739

95. Stoumpos S, Mark PB, McQuarrie EP, Traynor JP, Geddes CC (2017) Continued monitoring of acute kidney injury survivors might not be necessary in those regaining an estimated glomerular filtration rate $>60 \mathrm{~mL} / \mathrm{min}$ at 1 year. Nephrol Dial Transpl 32:81-88

96. The National Collaborating Centre for Chronic Conditions (UK) (2008) Chronic kidney disease: national clinical guideline for early identification and management in adults in primary and secondary care. Royal College of Physicians, London

97. Jafar TH, Stark PC, Schmid CH, Landa M, Maschio G, Marcantoni C, de Jong PE, de Zeeuw D, Shahinfar S, Ruggenenti P, Remuzzi G, Levey AS, AIPRD Study Group (2001) Proteinuria as a modifiable risk factor for the progression of non-diabetic renal disease. Kidney Int 60:1131-1140

98. Morris RL, Ashcroft D, Phipps D, Bower P, O'Donoghue D, Roderick P, Harding S, Lewington A, Blakeman T (2016) Preventing acute kidney injury: a qualitative study exploring 'sick day rules' implementation in primary care. BMC Fam Pract 17:91 